\title{
Hemelvaart en geloofsvorming in die skoolkonteks: 'n Ritueel-liturgiese verkenning
}

\author{
Van der Merwe, Gert Jacobus \\ Universiteit van Pretoria \\ gert@novitae.co.za \\ Wepener, Cas \\ Universiteit van Pretoria \\ Cas.wepener@up.ac.za
}

\begin{abstract}
Ascension Day and faith formation in the school context: A Ritual-liturgical exploration

The main aim of this article is to consider the value of special liturgical services in facilitating faith formation in children. Ideally liturgical rituals should be developed and performed in such a way as to recognise, respect and involve the full spectrum of human nature. This article focuses on 1 of 10 strategic recommendations developed from empirical qualitative research in the school context. The article closes with the pragmatic task by way of a proposal on the holistic design and use of liturgical rituals in the school context ${ }^{1}$ to deepen its potential in stimulating and facilitating faith formation in children.
\end{abstract}

Key words

Faith; liturgy; ritual; school; worship

1 Die navorser verwys in die strategiese voorstelle na 'skoolkonteks' en bedoel daarmee skole wat soortgelyke demografiese samestelling, teenwoordigheid van CSV, kultuur en Christelike etos vertoon. Die navorser is van mening dat kerke die navorsing oor kinders se belewenis van liturgiese rituele van waarde sal vind en dat verskeie toepassings suksesvol aangewend kan word om te help met die fasilitering van geloofsvorming in Christelike liturgiese kontekste. 


\section{Agtergrond}

Navorsing deur Nel \& Van der Westhuizen (reds.) (2015:191) wat in 2014 onder 16 tot 35 jarige wit Afrikaanssprekendes gedoen is, het bevind dat $70 \%$ van die deelnemers hul skool se geloofsaktiwiteite bywoon of bygewoon het. Die afleiding kan dus gemaak word dat blootstelling aan geloofsvormende stimuli vir dié kinders van groot waarde is. In 2013 was daar ongeveer 14 miljoen leerders in Suid-Afrikaanse skole (Statssa 2013:21). Binne die huidige Suid-Afrikaanse konteks waar die Organisasie vir GodsdiensteOnderrig en Demokrasie (OGOD) gepoog het om godsdiensbeoefening geheel en al uit die skoolkonteks te verwyder (Hooggeregshof van SuidAfrika 2017:1-34), is die rol, waarde en plek van godsdiensbeoefening in die skoolkonteks onder die vergrootglas. Outeur (2013:106-107) meen dat rituele in die skoolkonteks heelwat ooreenkomste met dié van die klassieke kerklike modelle toon. Deur die waarde van geloofsontwikkeling in die skoolkonteks duidelik te ondersoek, kan die kerk en samelewing 'n beter prentjie kry van die noodsaaklikheid van godsdiens en meer spesifiek, geloofsvorming in skole. Verdere navorsing oor die skoolkonteks en die wyse waarop liturgiese rituele 'n verdieping in geloofsvorming kan meebring, sal 'n waardevolle bydrae tot die veld wees.

Die navorsing wat in hierdie artikel aangebied word, het aangesluit en uitgebrei op navorsing wat ondersoek ingestel het oor die jeug en aanbidding (Sonnenberg \& Barnard 2008 \& 2012; De Wildt 2014; Smit, D. J. 2017), rituele in die skoolkonteks (Quantz et al. 2011; Ilosvay 2016; McLaren 1999), geloofsvorming van adolessente (Nel \& Van der Westhuizen 2015) en die rol van musiek en sang in liturgiese rituele (Klomp 2011; Saliers 1998 \& 2012). Hierdie navorsing het gefokus op die leemte m.b.t. die rol wat liturgiese rituele in geloofsvorming van kinders in die skoolkonteks speel. Ten tye van die finalisering van hierdie navorsing, was daar nie beduidende navorsing oor dié onderwerp in die Suid-Afrikaans konteks gedoen nie.

\section{Die doel van die navorsing}

Die navorsing het ten doel gehad om 'n teorie vir die praksis ten opsigte van die rol van liturgiese rituele op geloofsvorming in die skoolkonteks te skep. Volgens Heyns en Pieterse moet die praktiese teologie '... vasstel watter teorieë ten grondslag aan die praktyk lê en nagaan of dit doeltreffend 
is. As dit sou blyk dat hierdie teorieë nie doeltreffend is nie, is die taak van die Praktiese Teologie om nuwe teorieë te ontwikkel' (1990:22). Die navorser het spesifieke aspekte van liturgiese rituele in die skoolkonteks geïdentifiseer wat van waarde kan wees om geloofsvorming by kinders te fasiliteer. Insigte in die rol en funksionering van dié aspekte by liturgiese rituele het die navorser gehelp om strategiese voorstelle te maak wat van waarde kan wees om bestaande en nuut-geskepte liturgiese rituele se invloed en betekeniswaarde op geloofsvorming van kinders te verdiep. ${ }^{2}$

Die spesifieke en oorkoepelende navorsingsvraag was: 'Wat is die kenmerkende eienskappe van liturgiese rituele wat op 'n betekenisvolle wyse geloofsvorming binne 'n skoolkonteks kan bevorder?'

Hierdie kernvraag is deur 8 sub-vrae aangevul:

1. Wat is rituele en hoe word rituele in die skoolkonteks geïdentifiseer?

2. Watter liturgiese rituele is reeds in die skoolkonteks teenwoordig?

3. Hoe kan ontwikkelingsielkunde lig werp oor hoe liturgiese rituele 'n rol speel in geloofsvorming?

4. Wat is die aspekte van liturgiese rituele wat 'n betekenisvolle invloed op geloofsvorming binne die skoolkonteks uitoefen?

5. Wat is die rol wat musiek binne liturgiese rituele speel om geloofsvorming te versterk en te verdiep?

6. Wat is die kontekstuele kenmerke waar liturgiese rituele sinvol kan funksioneer?

7. Hoe kan diesulke eienskappe en kenmerke betekenisvol benut word om in multikontekste as geloofsvormende stimuli te funksioneer?

8. Hoe kan bestaande liturgiese rituele in die skoolkonteks aangepas word om die invloed op geloofsvorming te verdiep?

2 Die navorser erken dat sy eie teologiese agtergrond onbewustelik die evaluasie sou beïnvloed en dat 'n ander navorser moontlik ander aspekte sou kon identifiseer of ander ontdekkings sou kon maak (Osmer 2008:616). 


\section{Metodiek}

Die navorsing is gedoen aan die hand van fenomenologiese navorsing (Lichtman 2014:111; Osmer 2008:627-664) as oorhoofse navorsingstrategie en het gebruik gemaak van 'n interdissiplinêre literatuurstudie om die reflektiewe kwalitatiewe empiriese praktyknavorsing te ondersteun (Osmer 2011:1-2; Pieterse 2011:720). Die navorsingsontwerp het bestaan uit drie fases van praktyknavorsing en 'n interdissiplinêre literatuurstudie (Osmer 2008:612).

Die navorsing is uitgevoer in drie skole in Gauteng. ${ }^{3}$ Die laerskool is 'n enkelmedium skool met Afrikaans as voertaal, 98\% wit en $2 \%$ swart kinders $^{4}$ (leerders). Ten tye van die navorsing was daar 722 kinders in die skool waarvan 5 kinders in pleegsorg was en 34 kinders subsidies vir skoolgelde ontvang het. Die graad 7-groep het bestaan uit 95 kinders waarvan 73 deelgeneem het aan die navorsing.

Hoërskool A is 'n dubbelmedium skool met Engels en Afrikaans as voertaal. Die skool het ten tye van die navorsing 740 kinders gehad, waarvan 496 seuns; 244 dogters; 250 Engelssprekend; 705 wit; 30 swart; 3 Indiër en 2 kleurlinge was. 88 kinders het subsidie ontvang. Die deelnemers van die skool was saamgestel uit 9 kinders in graad 8 en 7 kinders in graad 12. Die graad 8 jaargroep het bestaan uit 174 kinders waarvan 118 Afrikaanssprekend en 56 Engelssprekend was. Die graad 12 jaargroep het bestaan uit 122 kinders waarvan 71 Afrikaanssprekend en 51 Engelssprekend was.

Hoërskool B is 'n enkelmedium skool met Afrikaans as voertaal. Die skool het ten tye van die navorsing 811 kinders gehad, saamgestel uit 801 wit, 10 swart en 3 kleurling kinders. 72 kinders het subsidie ontvang. Die deelnemers (29 in Fase 2 en 31 in Fase 3) van die skool was almal in graad 9. Die graad 9 jaargroep het bestaan uit 156 kinders waarvan 88 dogters en 68 seuns was.

3 Alle religieuse aktiwiteite by die betrokke skole het plaasgevind onderworpe aan die Grondwet van die Republiek van Suid-Afrika, Wet 108 van 1996, Suid-Afrikaanse Skolewet, Wet 84 van 1996, en die relevante beleide van die betrokke skole.

4 Vir die doel van hierdie navorsing, het die navorser met die woorde 'kind' en 'kinders' verwys na skoolgaande jongmense tussen die ouderdomme van 6 en 18 en word die pedagogiese terme kleuter, kind en adolessent saamgevat in die een term. Die navorser gebruik die term ook om na leerders in die skoolkonteks te verwys. 
Die navorser het, soos reeds vermeld, fenomenologiese navorsing as oorhoofse navorsingstrategie gebruik omdat dit die diepgaande belewenisse en geleefde ondervindinge van individuele persone, wat 'n spesifieke gebeurtenis beleef het, beskryf (Lichtman 2014:111; Osmer 2008:752-754). Die navorser het deur middel van dié strategie, spesifieke geleenthede en aktiwiteite van groepe mense deur middel van deelnemende observasie beskryf. Die navorser het verskeie geleefde belewenisse gebruik om gemene ontdekkings te maak oor die waarde en doel van sekere aksies en handelinge. Byvoorbeeld: na die analise van verskeie deelnemers se beskrywings van die waarde wat liturgiese musiek (Gospel musiek) vir hulle inhou, kon die navorser ontdek dat die keuse om na dié musiek te luister, nie primêr beïnvloed word deur die musiek se opgewekte melodie of ritme nie, maar dui op 'n behoefte om God se Woord vanuit die musiek te hoor (Osmer 2008:627-664; Outeur 2017:278).

Daar is sterk gesteun op Osmer (2008:93) se vier take van 'n praktiesteologiese navorser naamlik: beskrywend-empiriese taak (wat gebeur?); interpreterende taak (waarom gebeur dit?); normatiewe taak (wat behoort te gebeur?); en die pragmatiese taak (hoe kan ons hierop reageer?). Binne hierdie algemene benadering is gebruik gemaak van 'n literatuurstudie asook empiriese navorsing.

'n Interdissiplinêre literatuurstudie is veral gepas vir liturgiese navorsing (Barnard et al. 2014:50). Verskillende dissiplines, in hierdie geval teologie, rituele navorsing en ontwikkelingsielkunde, het lig gewerp op geloofsvorming van kinders. Die literatuurstudie help die navorser veral in die normatiewe taak ${ }^{5}$ (Osmer 2008:93) en begelei die navorser na 'n beter verstaan van die spesifieke elemente sodat die navorser beter toegerus is om die dinamiese wisselwerking van die aspekte in die skoolkonteks te identifiseer. Die literatuurstudie is ook gebruik om relevante vrae vir beide gestruktureerde en semi-gestruktureerde onderhoude en vraelyste te identifiseer (Woodward \& Pattison 2000:15; cf. Grimes 2013:329; cf. Barnard et al. 2014:50). Op die manier word verskillende aspekte van 'n saak vanuit verskillende dissiplines belig en al die dissiplines word deur die navorsing verryk aangesien die navorsing op konvergensiesones van die betrokke dissiplines plaasvind (Madni 2007:3).

5 Die literatuur kan tereg met al die take van waarde kan wees. 
'n Kwalitatiewe navorsingsmetode, wat ondersteun is deur'n kwantitatiewe data-analise (Babbie 2010:11, 18, 391, 423), is gebruik omdat dit 'n gepaste metode is waarmee empiriese navorsing vanuit'n hermeneutiese invalshoek gedoen kan word (Pieterse 2011:734-735), en word dikwels gebruik vir die akademiese prosedure in liturgiese navorsing (Barnard et al. 2014:50). Die doel van kwalitatiewe navorsing is om te ontdek, om te beskryf, om te verstaan, of om 'n fenomeen te verklaar (Lichtman 2014:28). 'Qualitative research seeks to understand the actions and practices in which individuals and groups engage in everyday life and the meanings they ascribe to their experience. Qualitative research is better suited to studying a small number of individuals, groups, or communities in depth' (Osmer 2008:627).

Die doelwit was om nuwe data, wat lig kon werp op die rol wat liturgiese rituele in die skoolkonteks op geloofsvorming uitoefen, te genereer. Omdat die navorser iets oor die rituele moes sê wat deelnemers nie gesê het nie (Grimes 2013:69), is die navorser telkens deur die antwoorde van deelnemers gelei om opvolg vrae te vra wat meer op spesifiek aspekte gefokus het (Grimes 2013:47-49). So het die navorser bv. tydens gesprekke opgelet dat deelnemers spontaan bewegings saam met 'n liedjie gedoen het, wat na vrae oor bewegings tydens sang gelei het. Die navorser het intensioneel heen en weer beweeg tussen data insameling, analise en refleksie en gebruik gemaak van 'n tegniese prosedure van vyf stappe, wat die navorser begelei het om 'n nuwe basisteorie vir die spesifieke konteks te skep (Osmer 2008:645).

Die liturgiese rituele in die skoolkonteks is geïdentifiseer, beskryf en ondersoek (Grimes 2013:60), gerugsteun vanuit die verskeie literatuurstudies, en deur middel van 'n kombinasie van observasie (Babbie 2010:24; Bryman 2012:277), deelname (Grimes 2013:24), semigestruktureerde vraelyste (Babbie 2010:262-269), semi-gestruktureerde onderhoude (Wepener 2005:8; cf. Hancock 2006:41-44), beplanning- en uitvoer van onderhoude (Thumma 1998:204; Osmer 2008:787-788); en die analise van data (Babbie 2010:11, 18, 391, 423).

Die $2^{\text {de }}$ - en $3^{\text {de }}$ Fase van die praktyknavorsing is uitgevoer in hoërskool B. Sommige van die deelnemers wat in Fase 1 op laerskool was, en deelgeneem het aan die navorsing, is nou op hoërskool. Dit is twee jaar later en die navorser kry die geleentheid om die liturgiese rituele, na aanleiding van 
insigte verkry uit die literatuurstudie en verkennende praktyknavorsing, te herbesoek. Die navorser het gevolglik die unieke geleentheid gekry om deelnemers se opinie en belewenis van die ooreenkomste en verskille van liturgiese rituele tussen die hoërskool en die laerskool te ondersoek. 'n Doelgerigte fokus op die anonimiteit van deelnemers, was deurslaggewend gewees om die kinders se diepste emosies, opinies en oortuigings tydens die praktyknavorsing te verhaal (Babbie 2010:67).

Die semi-gestruktureerde vraelyste is opgestel na aanleiding van insigte verkry uit die verkennende praktyknavorsing en die literatuurstudie (Babbie 2010:262-269). Die navorser het telkens by elke vraag, of groep vrae, die identifisering, agtergrond en die rede vir die vraag aan die deelnemers verduidelik. Data vanuit die semi-gestruktureerde vraelyste uit Fase 2 is verfyn (Bryman 2012:386) en aangevul met insigte verkry vanuit die literatuurstudie (Outeur 2017:229-231), waarna die deelnemers in Fase 3 genader is om hul opinie rakende sekere aspekte van die Hemelvaartdiens, CSV, en musiek en sang met behulp van 'n $2^{\text {de }}$ semi-gestruktureerde vraelys te toets en te verfyn.

Om die data te kwantifiseer, is deelnemers gevra om 'n beperkte aantal aspekte uit 'n lys te kies en die keuses te gradeer in volgorde van belangrikheid. Dit het die deelnemers forseer om oor die aspekte se betekeniswaarde ${ }^{6}$ na te dink sodat hulle dit kon evalueer in terme van hul persoonlike belewenis. Dit het 'n verdere kwantitatiewe analise moontlik gemaak (Babbie 2010:24; Bryman 2012:36, 331, 638-643).

Die kwalitatiewe data van Fase 3 is verder d.m.v. 'n kwantitatiewe dataanalise geanaliseer (Bryman 2012:638-643) om tendense uit te lig (Osmer 2008:627; cf. Bryman 2012:36) (Tabel 1, Figuur 1 en Tabel $2^{7}$ ) en is gebruik om die kwalitatiewe data te ondersteun en te verdiep (Bryman 2012:638-

6 Deelnemers se keuses is gradeer in volgorde van belangrikheid deur'n hoër waarde aan hul eerste keuse te heg en progressief ' $n$ laer waarde aan die $2^{\text {de }}, 3^{\text {de }}$ en $4^{\text {de }}$ keuse te heg. Die eerste keuse het telkens 4 punte getel, die $2^{\text {de }}$ keuse 3 punte, die $3^{\text {de }}$ keuse 2 punte en die $4^{\text {de }}$ keuse 1 punt. Die resultaat van die verwerking kan in kolom 'Betekeniswaarde' gesien word (Tabel 1). Twee deelnemers het nagelaat om hul gradering aan te dui. Hierdie deelnemers se keuses is gevolglik nie by 'Betekeniswaarde' ingereken nie. Die hoogste moontlike betekeniswaarde is dus 116 omdat daar 29 deelnemers is wat 'n maksimum van 4 punte kon toeken.

7 Slegs die Hemelvaartdiens se inligting van die data-analise is in hierdie artikel beskikbaar gestel. 
643). Die proses maak statistiese vergelyking en analise moontlik (Babbie 2010:24; cf. Bryman 2012:331). Deelnemers is aangemoedig om hul denke en emosies m.b.t. die vraag op skrif te stel, bv. 'Kan jy meer vertel van hoe jy nou voel as jy daaraan dink? Wat gaan deur jou gedagtes?'

Die opmerkings van deelnemers is telkens as deel van die analise van die aspekte by die rapportering ingesluit om die kwalitatiewe aard van die navorsing te onderstreep en om perspektief op die deelnemers se belewenis te gee (Bryman 2012:470). Die verdere kwantitatiewe data-analise het noemenswaardige resultate gelewer.

\section{Hemelvaartdiens as 'n spesiale liturgiese geleentheid}

Tabel 1, Figuur 1 en Tabel 2 reflekteer die kwantitatiewe data-analise van die deelnemers se perspektief op die aspekte betrokke by die Hemelvaartdiens.

\begin{tabular}{cc|c|c|c}
$\begin{array}{c}\text { Betekenis- } \\
\text { waarde }\end{array}$ & Aantal gekies & $\mathbf{1}^{\text {ste }}$ keuse & $2^{\text {de }}$ keuse & $1^{\text {ste }} \boldsymbol{2} 2^{\text {de }}$ keuse \\
\hline 72 & 24 & 12 & 5 & 17 \\
\hline 57 & 21 & 6 & 9 & 15 \\
\hline 51 & 18 & 8 & 4 & 12 \\
\hline 40 & 22 & 2 & 3 & 5 \\
\hline 24 & 14 & 0 & 3 & 3 \\
\hline 20 & 9 & 1 & 3 & 4 \\
\hline 14 & 7 & 0 & 2 & 2 \\
\hline 6 & 5 & 0 & 0 & 0 \\
\hline 6 & 4 & 0 & 0 & 0 \\
\hline 0 & 0 & 0 & 0 & 58 \\
\hline 290 & 124 & 29 & 29 & 0 \\
\hline
\end{tabular}

Tabel 1. Fase 3 vraelys-analise van vraag 1: Hemelvaartdiens 


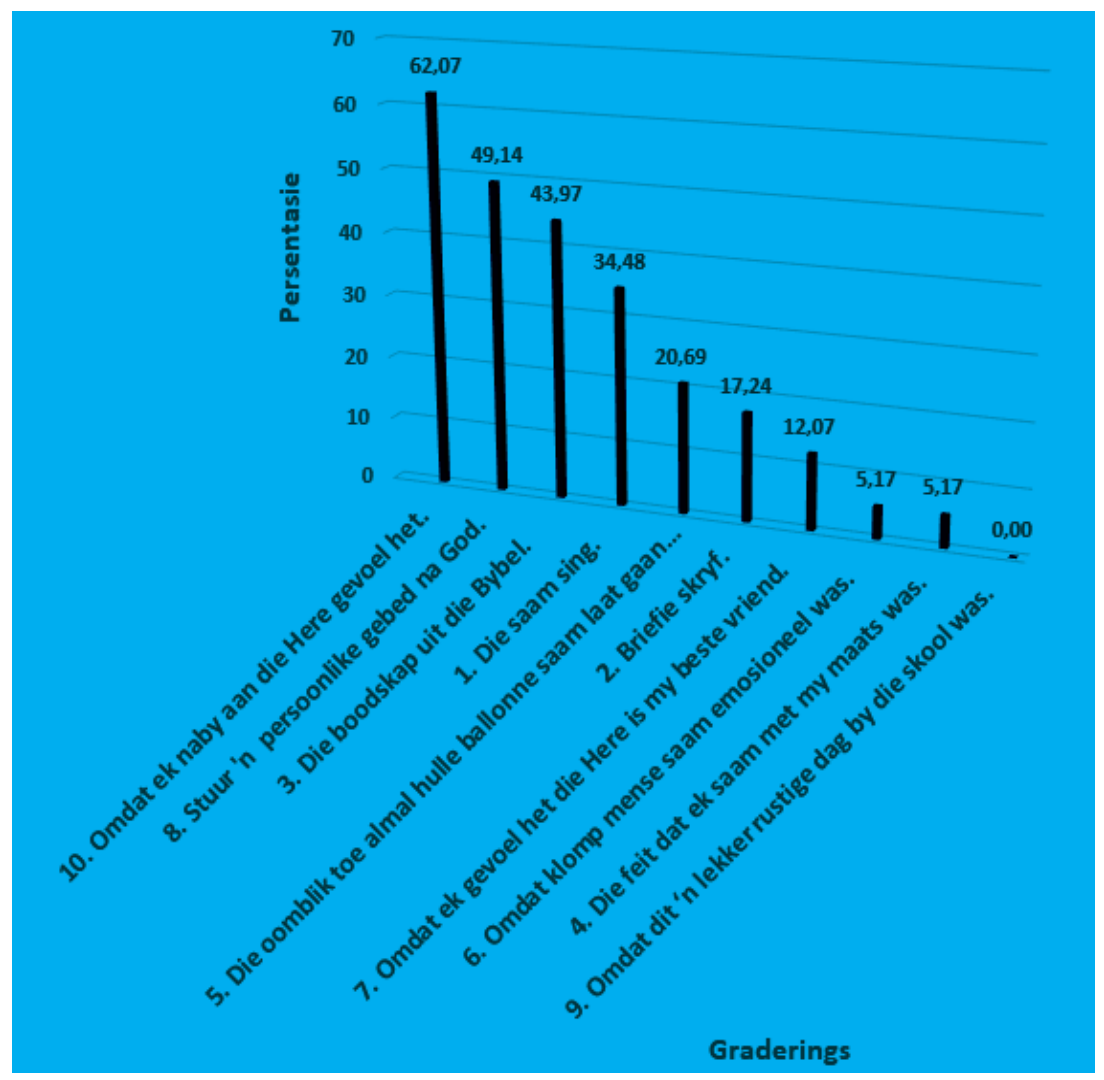

Figuur 1. Hemelvaartdiens betekeniswaarde \% bereken uit totale punt van 116 


\begin{tabular}{|c|c|c|c|c|}
\hline & & Gemiddelde & $\begin{array}{l}\text { Standaard } \\
\text { Afwyking (s) }\end{array}$ & $\begin{array}{l}\text { Koëffisiënt } \\
\text { van variasie } \\
\%\end{array}$ \\
\hline Aspek 10 & $\begin{array}{l}\text { Omdat ek naby aan } \\
\text { die Here gevoel het. }\end{array}$ & 3.13 & 1.10 & 35.13 \\
\hline Aspek 8 & $\begin{array}{l}\text { Stuur'n persoonlike } \\
\text { gebed na God. }\end{array}$ & 3.00 & 0.94 & 31.43 \\
\hline Aspek 3 & $\begin{array}{l}\text { Die boodskap uit die } \\
\text { Bybel. }\end{array}$ & 3.00 & 1.17 & 39.09 \\
\hline Aspek 1 & Die saam sing. & 1.90 & 1.00 & 52.25 \\
\hline
\end{tabular}

Verskeie insigte en ontdekkings is gemaak vanuit die data-analise, en het onder andere gelei tot die skepping van die strategiese voorstelle vir die holistiese gebruik van liturgiese rituele in die skoolkonteks (sien Figuur 2). Die onderstaande opmerkings oor die data-a nalise van die Hemelvaartdiens is in hierdie artikel van toepassing om die argument vir die rol en waarde van spesiale liturgiese geleenthede by geloofsvorming te ondersteun.

\subsection{Deelnemers het 'n behoefte om die Here se teenwoordigheid te beleef}

'Omdat ek naby aan die Here gevoel het' verdien 'n betekeniswaarde van 62.07\% (72 uit 'n moontlike 116) wat dit eerste plaas. 24 deelnemers (77\%) mak die keuse. Dit is 12 deelnemers se eerste keuse en 5 deelnemers se $2^{\text {de }}$ keuse. Dit is duidelik dat die behoefte om die Here se teenwoordigheid te beleef van groot belang is. Deelnemers het dié belewenis tydens die Hemelvaartdiens gehad en sien dit as 'n baie belangrike aspek wat hulle steeds onthou. Die laer koëffisiënt van variasie by aspek 8 (Tabel 2) dui o.a. daarop dat meer deelnemers die aspek 'n hoë gradering gegee het en dat beide aspekte ( 8 en 10) vir die deelnemers van groot waarde was.

8 In statistiek is die koëffisiënt van variasie, ook bekend as relatiewe standaardafwyking, 'n gestandaardiseerde maatstaf van verspreiding van 'n frekwensieverdeling. Koëffisiënt van variasie $=$ s/gemiddelde $\mathrm{x} 100 \%$. Hoe kleiner die koëffisiënt van variasie, hoe minder varieer die deelnemers se graderings rondom die gemiddelde. D.w.s die deelnemers voel meer eenstemmig oor die aspek onder bespreking. 
'Omdat ek naby aan die Here gevoel het', het gesamentlik met CSV, Hemelvaart, en musiek en sang gesien, die hoogste betekeniswaarde van 170 ontvang. Die navorser het hieruit afgelei dat liturgiese rituele in die betrokke konteks spesifiek ontwerp moet word om aan hierdie behoefte te voldoen (Outeur 2017:273). Die deelnemers se kommentaar bied 'n besonderse perspektief op die kwalitatiewe aard van die navorsing en kan nie oorgeslaan word nie.

- 'Ek mis die Hemelvaart - alles wat ons gedoen het- alles kom terug. Alles is net herinneringe. Ek voel asof die Here weer by my is. Ek wil graag weer so iets doen' (B26-1).

- 'Die samesang is lekker want almal jubel en juig vir die Here. Die boodskap uit die Bybel was 'n lekker beginsel en 'n les vir die dag. Omdat ek naby aan die Here was en dat Hy my beste vriend is, en dit maak my bly' (B16-1).

- 'Die Here is daar vir almal, maar om by die skool so 'n aktiwiteit te doen, laat 'n mens net nog nader aan Hom voel' (B23-1).

- 'Die saam sing en gebede uit die Bybel laat my nader aan die Here voel en ek voel veilig. Om 'n persoonlike gebed op na God te stuur is baie spesiaal en dit gee my die geleentheid om my gevoelens en emosies met Hom te deel' (B31-1).

- 'Om 'n persoonlike gebed aan God te stuur en 'n boodskap uit die Bybel te hoor is nie minder belangrik nie, dit is net baie belangrik om na aan die Here te voel omdat mens net so naby aan die Here is as wat jy kies om te wees, dus is ek altyd naby Hom' (B28-1).

- 'Ek voel hartseer want ek sal dit rêrig graag weer wil doen' (B30-1).

\subsection{Die kinders het 'n behoefte om 'n persoonlike gebed tot God te rig} 'Omdat ek geleentheid gegee is om 'n persoonlike gebed aan God te stuur' verdien 'n betekeniswaarde van $49.13 \%$ (57 uit 'n moontlike 116) wat dit tweede plaas, 21 deelnemers (67\%) kies die aspek, 6 deelnemers sien dit as die belangrikste aspek en dit is 9 deelnemers se $2^{\text {de }}$ keuse.

- 'Vir my was dit vreeslik mooi om so met die Here te kommunikeer en om almal in so 'n groep dieselfde gevoel te kry' (B20-1). 
- 'Gelukkig. Dit maak my bly dat ons so 'n tyd saam met almal vir ons Here gehad het. 'Upset' dat hoërskool dit nie doen nie. Was rêrig baie lekker om elkeen saam 'n boodskap vir God te stuur' (B8-1).

Deelnemer B15 se opmerking is noemenswaardig.

- 'Ek voel goed en gelukkig, want die Bybelvers het daai dag vir my 'n boodskap gebring toe ek saam sing het ek my hart uit gesing. Die briefie wat ek geskryf het, weet ek dat die gebed verhoor is, want kyk waar sit ek vandag - en hoe ver sou ek gekom het as dit nie vir Hom was nie?' (B15-1).

Die deelnemer beleef dat sy/haar gebed verhoor is. Die implikasies is verrykend - veral m.b.t. die vertrouensverhouding wat tussen die deelnemer en God gevestig is.

\subsection{Die kinders dui aan dat 'n boodskap uit die Bybel 'n baie belangrike deel van dié liturgie is}

Die boodskap uit die Bybel verdien 'n betekeniswaarde van 43.97\% (51 uit 'n moontlike 116) wat dit derde plaas. 18 deelnemers maak die keuse, dit is 8 deelnemers se $1^{\text {ste }}$ keuse en 4 deelnemers se $2^{\text {de }}$ keuse. Woordverkondiging is duidelik baie belangrik en dit gaan nie vir die deelnemers net oor die belewenis nie. Woordverkondiging bly die fondasie van enige liturgiese ritueel (McClendon 2012:220-225) en kan vanuit 'n teologiese perspektief eerste geplaas word.

\subsection{Die kinders het 'n behoefte om op 'n konkrete manier uitdrukking te gee aan hul denke en emosies}

Die vrylating van die ballonne dui op die ekspressiewe-; die lasverligtendesowel as die kanaliserende dimensie (Lukken 1994:100-106; Wepener \& Van der Merwe 2009:206-209). Dit is 'n aspek van die ritueel waaroor daar met die oploop na die geleentheid heelwat afwagting geskep is (Outeur 2017:217). Die aspek verdien 'n betekeniswaarde van 20.69\% (24 uit 'n moontlike 116) wat dit vyfde plaas. 14 deelnemers maak die keuse en dit is 3 deelnemers se $2^{\text {de }}$ keuse. Die aspek van die ritueel verwys na die samevatting van deelnemers se verwagtinge - die oomblik toe deelnemers hul gebede, briefies en emosies kon laat gaan. Dit is die oomblik wat emosies tot op 'n punt gedryf is en die trane, in sommige gevalle, begin vloei het: 
'Ek wil sommer huil - dit is vir my te emosioneel' (Onderwyser E) (Outeur 2017:411).

- 'Dit was 'n wonderlike dag saam met die Here en ons vriende. Toe almal die ballonne laat gaan - het almal meer gelukkig geraak' (B19-1).

- 'Dit was so 'n warm gevoel wat ek gekry het toe almal gelyk die ballonne opgestuur het en elkeen 'n briefie daaraan vasgemaak het wat vir hom/haar baie beteken het' (B9-1).

- 'Die ballonne was 'n goeie manier om uit te beeld dat Jesus opgegaan het hemel toe, maar die diens het ons wel laat besef dat hy terug gaan kom om ons te kom haal' (B27-1).

'n Bykomende, konkrete aspek van die Hemelvaartdiens was die geleentheid om voor die tyd 'n boodskap vir 'n ander persoon of vir God op 'n briefie te skryf. Die kinders het meer as gebede geskryf. Dit was 'n proses gewees wat deel was van die voorbereiding van die Hemelvaartdiens (Outeur 2017:217). Dit was drome, versoeke tot vergifnis en boodskappe vir iemand wat dalk die briefie mag optel - 'n wens om iemand in nood te help. Die geleentheid om 'n briefie te skryf verdien 'n betekeniswaarde van $17.24 \%$ (20 uit 'n moontlike 116) wat dit sesde plaas. 9 deelnemers maak die keuse, dit is 1 deelnemer se $1^{\text {ste }}$ keuse en 3 deelnemers se $2^{\text {de }}$ keuse.

- 'Ek onthou nog hoe dit gevoel het toe ons almal saam kon dans en sing op die paviljoene. Dit was 'n spesiale gedagte dat ons al ons probleme en bekommernisse kon neerskryf en net laat gaan. Ongelukkig 'n belewenis wat ek nooit weer beleef het nie' (B12-1).

- 'Ek verlang na die laerskool, die feit dat ek baie nader aan God was in die laerskool a.g.v. die CSV en al die openinge. Die Hemelvaartdiens was elke jaar vir my 'n spesiale dag omdat ek 'n briefie aan die Here kon skryf oor my gedagtes en bekommernisse' (B13-1).

- 'Dit was so 'n warm gevoel wat ek gekry het toe almal gelyk die ballonne op gestuur het en elkeen 'n briefie daaraan vasgemaak het wat vir hom/haar baie beteken het' (B9-1).

- 'Vry om God by die skool te aanbid deur'n opening, gebed en samesang. Bly om 'n brief te kon skryf en iemand dalk gehelp het as hulle die brief opgetel het en kon lees' (B14-1). 


\section{Slotsom: ritueel-liturgiese roetemerkers met die oog op geloofsvorming}

Aanbidding is drama wat deelnemers bewus maak van die grootsheid van die gebeurtenis. Die deelnemers is die akteurs en God is die gehoor, alhoewel God ook inderdaad aktief in en deur die gebeure werksaam is (Wepener 2016:1). In die dramatiese narratief is elemente opgesluit wat ontgin kan word om deelnemers sinvol deel te maak van die gebeure, en om die grootsheid van die gebeure te beklemtoon (Long 2001:44 \& 52). Die Hemelvaartdiens het 8 van die 9 dimensies van rituele betrek (Lukken 1994:100-106; Wepener \& Van der Merwe 2009:206-209) wat kan verklaar waarom deelnemers die geleentheid as noemenswaardig beskou het. Daar is ' $n$ verskil in die aanbieding, inhoud en fokus tussen die Hemelvaartdiens en die CSV-geleenthede, want aansienlik meer deelnemers (7) het die belewenis van God as 'n vriend by die Hemelvaartdiens gekies (Outeur 2017:251). Verskeie deelnemers se opmerkings gee perspektief hierop:

- 'Ek mis die Hemelvaart - alles wat ons gedoen het - alles kom terug. Alles is net herinneringe. Ek voel asof die Here weer by my is. Ek wil graag weer so iets doen' (B26-1).

- 'Die Hemelvaartdiens was elke jaar vir my 'n spesiale dag omdat ek 'n briefie aan die Here kon skryf oor my gedagtes en bekommernisse' (B13-1).

- 'Dit maak my gelukkig om daaraan te dink omdat dit so 'n spesiale dag was. Ek voel 'n soort van warmte in my hart. Ek voel bly daaroor' (B1-1).

- 'Ek voel goed en gelukkig, want die Bybelvers het daardie dag vir my 'n boodskap gebring - toe ek saam sing, het ek my hart uit gesing. Weens die briefie wat ek geskryf het, weet ek dat die gebed verhoor is, want kyk waar sit ek vandag - en hoe ver sou ek gekom het as dit nie vir Hom was nie?' (B15-1).

- 'Die saam sing en gebede uit die Bybel laat my nader aan die Here voel en ek voel veilig. Om 'n persoonlike gebed aan God te stuur is baie spesiaal en dit gee my die geleentheid om my gevoelens en emosies met Hom te deel' (B31-1). 
- 'Ek voel dat hierdie 'n baie spesiale dag was, want kort daarna was ek aangeraak deur die Heilige Gees. Kort daarna bedoel ek so week of twee' (B7-1).

- 'Ek het dit geniet om meer te weet van my geloof en dit was lekker omdat ek van Graad 7 af regtig God se goedheid rondom my begin sien het' (B4-1).

Die Hemelvaartdiens is saamgestel uit 'n omvattende reeks rituele wat konkrete, eksistensiële belewenisse fasiliteer het (Louw 1990:325-326; De Villiers \& Prins 1984:136). Die spesiale gebruik van konkrete voorbeelde die ballon en briefie - wat direk gekoppel is aan kognitiewe persoonlike deelname (Wepener \& Van der Merwe 2009:206-209; Babin \& Iannone 1991:20-22; De Villiers \& Prins 1984:136), was in die spesifieke konteks uniek aan die Hemelvaartdiens.

Die spesifieke fokus op gebed het vir die deelnemers uitgestaan. Die gebed word saam met die ballon in die lug ingestuur, simbolies van Jesus se Hemelvaart en 'n konkrete wyse waarop die gebed aan God 'gestuur' word. Die deelnemers het 'n spesifieke langtermyn herinnering aan die geleentheid gehad. Selfs net om aan die Hemelvaartdiens terug te dink, was van groot waarde vir die deelnemers, selfs twee jaar later. Die feit dat die deelnemers nie noodwendig die spesifieke boodskap of gebed kon onthou nie, het geen verskil gemaak aan die invloed wat die gebeure op hulle gehad het nie - die liturgiese ritueel het hulle diep geraak.

Die herinnering aan die Hemelvaartdiens het gedagtes oor hul geloofslewe by sommige deelnemers wakker gemaak en laat deelnemers selfs nader aan die Here voel. Die herinnering aan die ritueel het in wese impak op hul emosionele geheue gehad. Dit het goeie herinneringe wakker gemaak wat gelei het na 'n herbelewing van die dag, en 'n herbelewing van God se teenwoordigheid en betrokkenheid in hul lewens. Dit het gevolglik 'n daadwerklike invloed op die vorming en instandhouding van diepsinnige verhoudings gehad. 'n Aanbieding van die bevindinge van hierdie navorsing by 'n werkswinkel van die departement Praktiese Teologie, Universiteit van Pretoria, het verskeie positiewe opmerkings van studente oor persoonlike belewenisse van Hemelvaartdienste uit hul skooldae ontlok. Die herinnering aan die geleenthede het die studente, net 
soos vir die deelnemers, verskeie jare later nog opgewonde gemaak oor hul deelname aan die geleenthede. $\mathrm{Na}$ afloop van die aanbieding, het die navorser en studieleier die saak verder bespreek en ontdek dat hulle nie so 'n geleentheid tydens hul skooldae kon herroep nie, omdat Hemelvaart op daardie stadium 'n openbare vakansiedag was. Dit onderstreep die waarde van spesiale dienste wat fokus op spesifieke aspekte en verskeie dimensies betrek.

Dit is beredeneerbaar dat spesiale dienste so ingerig kan word om die fokus van die liturgiese ritueel op sekere aspekte te laat val. Dit kan die deelnemers die geleentheid gee om 'n belewenis van spesifieke aspekte van liturgiese rituele te beleef. So kan 'n liturgiese ritueel meer gefokus wees op lof en aanbidding, woordverkondiging, gebed, samesyn, of op die belewenis van God se teenwoordigheid. Dit beteken nie dat slegs een aspek teenwoordig is nie, maar wel dat die fokus meer op een of twee aspekte geplaas word, sodat deelnemers se gedagtes en emosies meer daarop ingestel is.

Dit is hier van kardinale belang by die ontwerp en uitvoer van die spesiale liturgiese rituele, dat die volle spektrum van menswees betrek word deur die sosiale-, intellektuele-, spirituele-, fisiese-, en emosionele aard en behoeftes van kinders in ag te neem (Scazzero 2014:18). Die briefie en/of gebed wat die deelnemers aan die ballon vasgemaak het, het eerstens hul intellektuele aard betrek deurdat hulle vooraf hul denke moes fokus op 'n gebed wat hulle vir hulself of vir iemand anders moes skryf. Die fokus op God deur middel van die woordverkondiging, lof en aanbidding en die afwagting van die viering van Hemelvaart het die spirituele aard betrek. Die sosiale aard is betrek deur deelname in 'n groot groep - wat die portuurgroep ingesluit het, sowel as die oproep om vir 'n ander persoon 'n gebed op te stuur. Die deelnemers is laastens fisies en emosioneel betrek deurdat hulle op 'n konkrete manier die gebed aan die ballon vasgemaak en laat gaan het. Dit het gelei tot 'n emosionele katarsis wat 'n blywende indruk op deelnemers se lewens gelaat het (Wepener \& Van der Merwe 2009:205). 'n Bykomende uitvloeisel van die liturgiese ritueel was dat deelnemers geleentheid gegee is om, deur middel van 'n gedeelde realiteit (Hardin \& Conley 2001:8), 'n diepsinnige verhouding met God te kon begin, of geleentheid gegee is om die bestaande verhouding te verdiep (Outeur 2017:300). 
Dit is dus wenslik dat spesiale dienste ontwerp en ingespan word om deelnemers deel te maak van 'n spesiale gebeurtenis, wat fokus op aspekte van persoonlike deelname deur middel van konkrete voorbeelde en wat die volle spektrum van menswees respekteer en betrek. Die implikasie is dat omvattende, logistiese ondersteuning vir die ontwerp en uitvoering van so 'n liturgiese gebeurtenis beskikbaar gestel moet word. Deelnemer B5-1 het opgemerk dat die spesiale geleentheid doelgerigte beplanning en opoffering vereis het: 'Die feit dat al die onderwysers so baie moeite daarin sit beteken baie vir my' (Outeur 2017:278).

Vir die navorser is die bestudering van rituele soortgelyk daaraan om met 'n flits in 'n donker kombuis in te stap en net te praat oor die deel waarop die flits op 'n spesifieke oomblik skyn (bv. 'n stoel), terwyl heeltyd in ag geneem moet word dat dit net een deel is van dit wat die kombuis 'n unieke vertrek maak. Die vertrek bestaan uit 'n stoof, tafel, opwasplek, implemente, ruimte, mure en foto's. Die vertrek kan net werklik verstaan word as ons besef dat dit 'n plek is waar geëet word, gewerk word, waar interaksie gestimuleer word, en 'n plek is waar verhoudings gebou en gevorm word. Die voorstelle wat die navorser hier mak, moet in hierdie lig gesien word. Elke aspek en voorstel moet gesien word binne 'n groter geheel en komplementeer mekaar binne 'n verweefde liturgiese mosaiek. Die kombuis, soos die liturgiese ritueel, bestaan om sekere uitkomste te fasiliteer. 'n Mens staan voor die keuse om die kombuis slegs te gebruik om in kos te maak, en so die volle potensiaal van die kombuis se invloed in die huis te verskraal. Net so kan 'n mens die fout maak om die volle potensiaal van liturgiese rituele te mis deur net een aspek daarvan te benut. Die strategiese voorstelle gee spesifieke doelwitte vir die ontwerp van liturgiese rituele in die skoolkonteks, sodat geloofsvorming beter gefasiliteer kan word. Dit kan soos volg voorgestel word: 


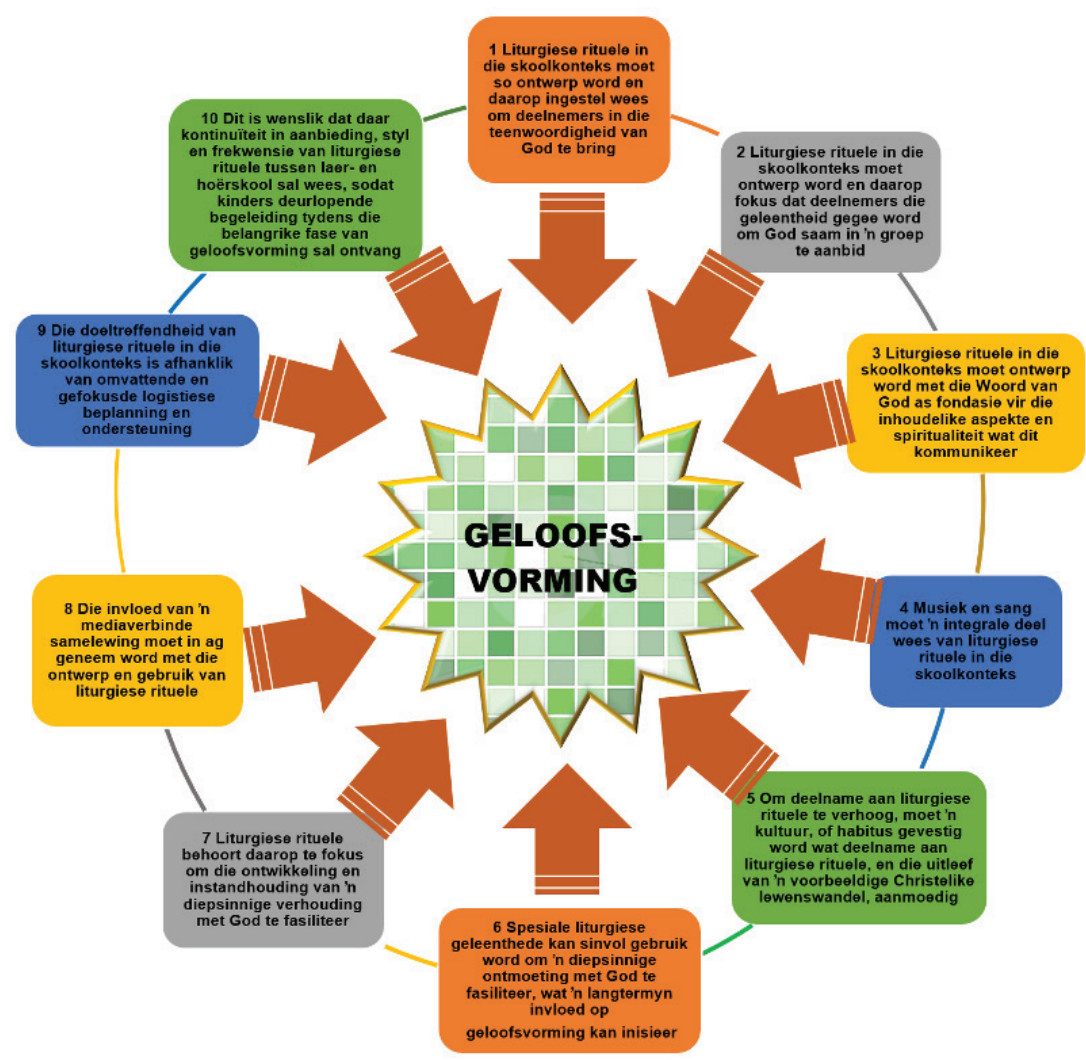

Figuur 2: Voorstelling van 'n holistiese gebruik van liturgiese rituele in die skoolkonteks

1. Liturgiese rituele in die skoolkonteks moet ontwerp word en daarop ingestel wees om deelnemers in die teenwoordigheid van God te bring.

2. Liturgiese rituele in die skoolkonteks moet ontwerp word en daarop fokus dat deelnemers die geleentheid gegee word om God saam in 'n groep te aanbid.

3. Liturgiese rituele in die skoolkonteks moet ontwerp word met die Woord van God as fondasie vir die inhoudelike aspekte en spiritualiteit wat dit kommunikeer. 
4. Musiek en sang moet 'n integrale deel wees van liturgiese rituele in die skoolkonteks.

5. Om deelname aan liturgiese rituele te verhoog, moet 'n kultuur, of habitus gevestig word wat deelname aan liturgiese rituele, en die uitleef van 'n voorbeeldige Christelike lewenswandel, aanmoedig.

6. Spesiale liturgiese geleenthede kan sinvol gebruik word om 'n diepsinnige ontmoeting met God te fasiliteer, wat 'n langtermyn invloed op geloofsvorming kan inisieer.

7. Liturgiese rituele behoort daarop te fokus om die ontwikkeling en instandhouding van 'n diepsinnige verhouding met God te fasiliteer.

8. Die invloed van 'n mediaverbinde samelewing moet in ag geneem word met die ontwerp en gebruik van liturgiese rituele.

9. Die doeltreffendheid van liturgiese rituele in die skoolkonteks is afhanklik van omvattende en gefokusde logistiese beplanning en ondersteuning.

10. Dit is wenslik dat daar kontinuiteit in aanbieding, styl en frekwensie van liturgiese rituele tussen laer- en hoërskool sal wees, sodat kinders deurlopende begeleiding tydens dié belangrike fase van geloofsvorming sal ontvang.

Wanneer die kerk of skool met geloofsvorming van kinders werk, is dit van kardinale belang dat die volle spektrum van menswees gerespekteer word deur die sosiale-, intellektuele-, spirituele-, fisiese-, en emosionele aard en behoeftes van kinders in ag te neem en te betrek. Dit is wenslik dat liturgiese rituele gebruik word om in hierdie behoeftes te voorsien (Scazzero 2014:18; Fowler \& Dell 2006:36; Wepener \& Van der Merwe 2009:205).

Die verskillende strategiese voorstelle kyk holisties na liturgiese rituele en geloofsvorming in die betrokke konteks. Soos 'n mosaïek, is die strategiese voorstelle so saamgestel, dat die optimale benutting van die verskillende dimensies en aspekte van liturgiese rituele, sowel as die volle spektrum van menswees, betrek word om geloofsvorming in die skoolkonteks te verdiep. 


\section{Literatuurverwysings}

Babbie, ER 2010. The practice of social research. Belmont, CA: Thomson.

Barnard, M \& Cilliers, J \& Wepener, C 2014. Worship in the Network Culture: Liturgical Ritual Studies: Fields and Methods, Concepts and Metaphors. Liturgia condenda, 28. Leuven etc.: Peeters.

Bryman, Alan 2012. Social Research Methods. $4^{\text {th }}$ ed. Oxford: Oxford University Press.

De Villiers, JL \& Prins, JMG 1984. Die Kerk en Sy Jeug op Weg. Kaapstad: N.G. Kerk-Uitgewers.

De Wildt, K 2014. With all senses: Something for body and mind: An empirical study of religious ritual in school. Garamond Verlag: Jena.

Fowler, JW \& Dell, ML 2006. 'Stages of faith From Infancy Through Adolescence: Reflections on Three Decades of Faith Development Teory.' Roehlkepartain, E.C. et al. (reds.). The Handbook of Spiritual Development in Childhood and Adolescence, 34-45. Thousand Oaks, California: Sage.

Grimes, RL 2013. The Craft of Ritual Studies. Kindle Edition: Oxford University Press.

Hancock, DR, \& Algozzine, R 2006. Doing case study research: A practical guide for beginning researchers. New York: Teachers College Press.

Heyns, LM \& Pieterse, HJC 1990. Eerste tree in Praktiese Teologie. Pretoria: Gnosis.

Hooggeregshof van Suid-Afrika, 2017. Saak nommer 29847/2014.

[Intyds] Beskikbaar: http://www.groundup.org.za/media/uploads/documents/ OGODJudgment.pdf [20 Augustus 2017]

Ilosvay, KK 2016. 'Religion in Schools? The Importance of Recognizing the Impact of Religious Experiences', The Journal of Faith, Education, and Community, Vol. 1, Iss. 2, Art. 2, 1-28.

Klomp, M 2011. The sound of worship: liturgical performance by Surinamese Lutherans and Ghanaian Methodists in Amsterdam. Leuven: Peeters. 
Lichtman, M 2014. Qualitative research for the social sciences. Thousand Oaks, California: SAGE Publications, Inc.

Louw, DA 1990. Menslike Ontwikkeling. Pretoria: Haum-Tersiêr.

Lukken, G 1994. 'No life without rituals', in Van Tongeren, L. \& C.

Caspers (reds.). Per Visibilia Ad Invisibilia. Anthropological, Theological and Semiotic Studies on the Liturgy and the Sacraments, 88-117. Liturgia Condenda 2. Kampen: Kok Pharos Publishing House.

Madni, AM 2007. 'Transdisciplinarity: Reaching beyond disciplines to find connections', Journal of Integrated Design \& Process Science, 11, 1, $1-11$.

McLaren, P 1999. Schooling as a Ritual Performance: Towards a Political Economy of Educational Symbols and Gestures. Third Edition. New York: Rowman \& Little.

Nel, M \& Van der Westhuizen, Z (reds.). 2015. Skokkend Positief: Insigte vanuit nuwe navorsing oor aktiewe Afrikaanse kerkjeug. Wellington: Bybelkor.

Osmer, R 2008. Practical Theology: An Introduction. Kindle Edition. Michigan: Eerdmans.

Osmer, RR 2011 'Practical theology: A current international perspective', HTS Teologiese Studies/Theological Studies 67(2), \#Art. 1058, 7 pages. http://dx.doi.org/10.4102/hts.v67i2.1058

Pieterse HJC 2011. 'Die noodsaak van die verrekening van metateoretiese aspekte.' Die Skriflig 45(4), 719-737.

Pondering Panda. 2014. 'The Pondering Panda Youth Report 2014', Pew Research. [Intyds] Beskikbaar: http://www.ponderingpanda.com [15 Januarie 2015]

Quantz, RA \& O’Connor, T \& Magnolda, P 2011. Rituals and Student Identity in Education: Ritual Critique for a New Pedagogy. New Work: Palgrave Macmillan.

Saliers, DE 1998. 'Liturgical Musical Formation.' Leaver R.A. \& Zimmerman, J.A. (reds.) Liturgy and Music: Lifetime Learning. 385-394. Collegeville: Minnesota. 
Saliers, DE 2012. 'Worship'. In Miller-McLemore, BJ (ed) The Willey Blackwell companion to Practical Theology, 289-298. Oxford: WileyBlackwell.

Scales, PC 2007. Spirituality and Adolescent Well-Being: Selected New Statistics. Minneapolis, Minnesota: Search institute.

Scazzero, P 2014. Emotionally healthy spirituality: it's impossible to be spiritually mature, while remaining emotionally immature. Grand Rapids, Michigan: Zondervan.

Smit, DJ 2017. 'What Makes Worship Good?', Ongepubliseerde artikel: Universiteit van Stellenbosch, 1-24.

Sonnenberg, PM \& Barnard, M 2008. 'God talk between beat and silence: Presentatie van een $\mathrm{PhD}$-project over youth worship in Protestantse contexten', Jaarboek Voor Liturgie-onderzoek 24, 177-197.

Sonnenberg, R \& Barnard, M 2012. 'Educating Young People through Christian Youth Worship: Reclaiming Space for Learning in Liturgical Contexts: Original Research'. HTS: Theological Studies, 68(2), 1-8.

Stats SA, 2013. 'General Household Survey 2013: Statsistical release P0318'. [Intyds]. Beskikbaar: www.statssa.gov.za [10 Februarie 2015].

Thumma, SL 1998. 'Methods for Congregational Study', in Ammerman, NT et al. Studying Congregations: A new handbook. Nashville: Abingdon Press.

Wepener, CJ 2005. 'Researching rituals: on the use of participatory action research in liturgical studies'. [Intyds] Beskikbaar: www.communitas.co.za, 1-15, http://communitas.co.za/blogs-communitas/padlangs/padlangs-gemeentes/ researching-rituals/ [15 April 2014]

Wepener, CJ 2016. 'Die liturgiese kategese van Mrs. Shea'. [Intyds] Beskikbaar: http://teo.co.za/die-liturgiese-kategese-van-mrs-shea-cas-wepener/ [29 Augustus 2017].

Wepener, CJ \& van der Merwe, J 2009. 'Ontdek die kenmerke en waarde van simbole en rituele', in Wepener, CJ \& van der Merwe, J (reds.), Ontdekkings in die erediens, 195-214. Wellington: Lux Verbi.

Woodward, J. \& Pattison, S 2000. The Blackwell reader in pastoral and practical Theology. Blackwell Publishers, Oxford. 